\title{
Interpersonal Competence in College Students with Cochlear Implants: A Preliminary Study
}

\author{
Young Mi Choi ${ }^{1,2}$, Hee Hwa Kim¹, Sung Wook Jeong', and Lee-Suk Kim ${ }^{2}$ \\ ${ }^{1}$ Department of Child Development \& Family Studies, Pusan National University, Busan; and ${ }^{2}$ Department of Otolaryngology-Head and \\ Neck Surgery, Dong-A University College of Medicine, Busan, Korea \\ 인공와우 이식 대학생의 대인관계 유능성 \\ 최영미 ${ }^{1,2} \cdot$ 김희화 $^{1} \cdot$ 정성욱 $^{2} \cdot$ 김리석 $^{2}$ \\ 부산대학교 아동가족학과, ${ }^{1}$ 동아대학교 의과대학 이비인후과학교실 ${ }^{2}$
}

Received July 2, 2017

Revised September 10, 2017

Accepted September 11, 2017

Address for correspondence

Sung Wook Jeong, MD, PhD

Department of Otolaryngology-

Head and Neck Surgery,

Dong-A University

College of Medicine,

26 Daesingongwon-ro, Seo-gu,

Busan 49201, Korea

Tel $+82-51-240-5423$

Fax $+82-51-253-0712$

E-mail dau_su@naver.com
Background and Objectives Although many studies have shown that cochlear implantation promotes restoration of adequate hearing and verbal ability, there is little research showing whether patients with cochlear implants (CI) adapted well to the society by forming a good interpersonal relationship. The purpose of this study was to investigate the interpersonal competence of college students who acquired good verbal ability through CI.

Subjects and Method Interpersonal competence was examined using the Korean version of interpersonal competence questionnaire. Participants were 23 college students with CI who had good verbal communication abilities. Their interpersonal competence was compared to that of 28 college students with normal hearing (NH). To identify the factors contributing to the interpersonal competence, regression analysis was performed using speech perception, vocabulary and speech intelligibility as independent variables.

Results College students with CI showed significantly weaker interpersonal competence than those with NH. Among 5 sub-factors of interpersonal competence, assertion and conflict management were not significantly different between two groups and initiation, caring others, and appropriate disclosure of CI group were significantly weaker than NH group. But college students with CI who had normal vocabulary and Speech Intelligibility Ratings score of 5 showed good interpersonal competence, which was comparable to those with $\mathrm{NH}$.

Conclusion College students with CI who acquired good verbal communication ability demonstrates lower interpersonal competence than those with NH. Therefore, it is necessary to support them to improve interpersonal competence as well as speech-language ability. Korean J Otorhinolaryngol-Head Neck Surg 2018;61(7):341-8

Key Words Cochlear implants · Interpersonal competence · Language ·

Speech Intelligibility.

\section{서 론}

대인관계 유능성(interpersonal competence)이란 타인과 관계를 형성하고 효과적으로 유지하는 능력을 의미한다. ${ }^{1)}$ 인

This is an Open Access article distributed under the terms of the Creative Commons Attribution Non-Commercial License (https://creativecommons.org/licenses/by-nc/4.0) which permits unrestricted non-commercial use, distribution, and reproduction in any medium, provided the original work is properly cited.
간은 대인관계를 통해 자아를 형성하고 발달시켜 가며 대인관 계에서 친화와 애정에 대한 욕구가 충족될 때 삶에서 만족감 을 느끼게 된다. ${ }^{2)}$ 또한 타인과의 원만한 관계 경험은 개인의 자존감, 인격 발달에 긍정적 영향을 미치고 사회적 적응을 돕는 반면 대인관계의 어려움은 우울, 불안, 외로움, 스트레 스 등과 높은 상관이 있다고 보고한 연구들은 대인관계가 개 인의 삶의 질과 정신건강에 중요한 영향을 미치는 요인임을 
말해준다. ${ }^{3-5)}$

Erikson ${ }^{6}$ 은 대학생에 해당하는 18 세 이후의 시기를 초기 성인기로 명명하고 친밀감을 형성하는 것이 이 단계의 주요 발달 과업이라고 설명하였다. 대학생 시기에는 폭넓은 대인관 계를 형성해 가는 것이 중요하고 만약 대인관계에서 친밀감 을 형성하지 못하면 긍정적인 자아 정체감을 확립하지 못하 게 되고 타인과의 사회적 관계에서 고립감을 경험하게 된다는 것이다. 한 연구에서 한국의 대학생들은 학창 시절에 입시 위 주의 교육으로 같은 학급 혹은 학원에서만 제한적으로 대인 관계를 맺으며 지내기 때문에 개인에게 관계 선택에 대한 자 유가 주어지는 대학 입학 초기부터 대인관계에서 많은 어려움 을 겪는 것으로 나타났다. ${ }^{7)}$ 대학생들의 대인관계 유능성은 대 학생활 적응도와 높은 상관이 있고 이 시기에 원만한 대인관 계가 형성되지 않은 상태로 대학을 졸업하게 되면 졸업 이후 취업이나 사회생활에도 문제가 이어지게 된다. ${ }^{8)}$ 그러므로 대 학생 시기의 대인관계 유능성은 이후 원만한 사회적 삶을 영 위하는 데 있어 매우 중요하다고 할 수 있다.

그러나 여러 연구에서 청각 장애 대학생들은 정상 청력 대 학생들로부터 분리와 소외를 경험하였고 대인관계의 어려움 으로 인해 정상 청력 대학생에 비해 외로움을 높게 지각하였 으며, 이들이 건청인과의 대인관계에서 겪는 어려움은 주로 제 한적인 구어 의사소통 능력에 기인하는 것으로 나타났다. ${ }^{9-13)}$

구어 의사소통 능력은 크게 듣기 능력과 언어 능력으로 나 눠지고 언어 능력은 수용언어 능력과 표현언어 능력으로 세 분화된다. 듣기 능력을 평가하는 여러 지표 중 말 지각력은 구어 의사소통 발달의 기초가 되는 듣기 능력이다. 어휘력은 다른 사람이 말한 내용을 이해하거나 자신이 말하고자 하는 내용을 형성하는 데 필수적인 능력으로써 수용언어 능력을 평 가하는 중요한 지표이고, 말 명료도(speech intelligibility ratings, SIR)는 실제 의사소통에서 사용되는 문장 수준의 표현언 어 능력을 평가하는 데 유용한 지표가 된다. 인공와우 이식을 받은 청각 장애인의 경우에는 유용한 청력을 획득하고 말 지 각력, 어휘력, 그리고 말 명료도 등의 검사에서 수행력이 우 수하다는 것이 많은 연구를 통해 확인되었다. ${ }^{14-17)}$ 하지만 이 러한 구어 의사소통 능력을 바탕으로 원활한 대인관계를 형 성하여 사회에서 잘 적응하고 있는지에 대해 살펴본 연구는
국내외적으로 매우 부족한 실정이다. 이에 본 연구에서는 인 공와우 이식을 받아 원활한 구어 의사소통 능력을 가진 청각 장애 대학생들의 대인관계 유능성을 알아보고자 하였다.

\section{대상 및 방법}

\section{대 상}

본 연구의 대상은 인공와우 이식수술을 받고 Categories of Auditory Performance 점수 7(친숙한 대상과 전화로 대화가 가능한 수준), 단음절 말 지각검사 음소 점수 $90 \%$ 이상, SIR 말 명료도 점수 4(말소리만으로 문장 발화가 명료하게 전달되는 수준) 이상으로 원활한 구어 의사소통 능력을 획득한 환자 중 통합 교육환경에서 성장하였고 현재 대학교에 재학 중인 18 30세 성인 23명이었다. 언어 습득 전 농 환자가 16명, 언어 습득 후 농 환자가 7명이었다. 대조군은 귀 질환의 과거력이 없으며 정상 청력을 가진 대학생 28명이었다(Table 1).

\section{대인관계 유능성 척도}

대인관계 유능성 척도는 Buhrmester 등 ${ }^{18)}$ 이 개발한 대인관 계 유능성 질문지(Interpersonal Competence Questionnaire, ICQ)를 Han과 Lee ${ }^{19}$ 가 한국 대학생을 대상으로 번안하고 타 당도를 검증한 대인관계 유능성 설문(Korean version of ICQ) 을 사용하였다. 본 척도는 5점 Likert 척도로 전혀 그렇지 않다 (1점)에서 매우 그렇다(5점)까지 응답하도록 되어 있고, 관계 형 성(initiation), 권리 주장(assertion), 타인 배려(caring others), 갈등 관리(conflict management), 자기 개방(self disclosure) 의 5 가지 하위 영역으로 구성되어 있다. 낯선 사람과 관계를 형성하고 개시하는 능력인 관계 형성 8문항, 권리를 침해당 했을 때 불쾌감을 표현하는 능력인 권리 주장 7문항, 상대방 이 필요할 때 도움이나 관심을 주는 능력인 타인 배려 7문항, 관계에서 갈등이 발생했을 때 대처하는 능력인 갈등 관리 6 문항, 자신의 민감한 정보나 약점을 적절히 노출하는 능력인 자기 개방 3 문항으로 이루어져 있으며 총점이 높을수록 대 인관계 유능성이 높음을 의미한다. 본 척도를 이용하여 인공 와우 이식 대학생과 정상 청력 대학생 간 대인관계 유능성을 비교하였다.

Table 1. Demographic data of college students with $\mathrm{Cl}$ and college students with normal hearing

\begin{tabular}{lccc}
\hline & $\begin{array}{c}\text { College student with } \mathrm{Cl} \\
\text { (prelingual deafness) }\end{array}$ & $\begin{array}{c}\text { College student with Cl } \\
\text { (postlingual deafness) }\end{array}$ & $\begin{array}{c}\text { College student with } \\
\text { normal hearing }\end{array}$ \\
\hline $\mathrm{n}$ & 16 & 7 & 28 \\
Chronoloical age (year) & $21.1( \pm 1.6)$ & $22.6( \pm 1.8)$ & $22.3( \pm 2.6)$ \\
Age at 1st Cl (year) & $7.4( \pm 2.4)$ & $12.6( \pm 4.7)$ & $10.0( \pm 4.5)$ \\
Duration of Cl use (year) & $13.7( \pm 2.7)$ &
\end{tabular}

Values are mean and standard deviation. $\mathrm{Cl}$ : cochlear implants 


\section{인공와우 이식 대학생의 대인관계 유능성에 영향을} 미치는 요인

인공와우 이식 대학생의 대인관계 유능성에 영향을 미치는 요인을 알아보기 위해 대인관계 유능성 척도검사 점수를 종 속 변인으로 하고, 구어 의사소통 능력의 주요 지표인 말 지각 력, 어휘력, 말 명료도를 독립 변인으로 하여 회귀 분석을 시행 하였다.

\section{결 과}

인공와우 이식 대학생과 정상 청력 대학생 간 동질성 검정

인공와우 이식 대학생과 정상 청력 대학생 간 연령과 성비 의 차이가 있는지 알아보기 위해 독립 표본 $\mathrm{t}$-검정과 교차 분 석을 실시하였다. 그 결과 두 집단의 연령 $(p=0.228)$ 과 성비 $(p=$ 0.382)의 유의한 차이는 없었다.

\section{인공와우 이식 대학생과 정상 청력 대학생의 대인관계 유능성}

인공와우 이식 대학생의 대인관계 유능성은 정상 청력 대학 생에 비해 부진하였다 $(p=0.002)$. 하위 영역별로는 관계 형성,
타인 배려, 자기 개방은 부진하였고 $(p=0.019, p=0.000, p=0.001)$ 권리 주장과 갈등 관리에서는 유의한 차이가 없었다 $(p=0.328$, $p=0.825$ )(Fig. 1).

\section{인공와우 이식 대학생의 대인관계 유능성에 영향을}

\section{미치는 요인}

인공와우 이식 대학생의 말 지각력은 단음절 말 지각검사로, 어휘력은 수용·표현 어휘력검사(Receptive \& Expressive Vocabulary Test)로, 그리고 말 명료도는 SIR로 평가하였다 (Table 2). 말 지각력, 어휘력, 그리고 말 명료도를 독립 변인 으로 하여 인공와우 이식 대학생들의 대인관계 유능성에 영향 을 미치는 요인을 알아본 결과, 어휘력과 말 명료도가 인공와 우 이식 대학생의 대인관계 유능성에 영향을 미치는 것으로 나타났다. 인공와우 이식 대학생의 대인관계 유능성에 대해 어휘력이 $29.6 \%$, 말 명료도가 $17.7 \%$ 의 설명력을 가지고 있었 다(Table 3).

\section{어휘력과 말 명료도에 따른 인공와우 이식 대학생의 대인관계 유능성}

회귀 분석 결과, 인공와우 이식 대학생의 대인관계 유능성

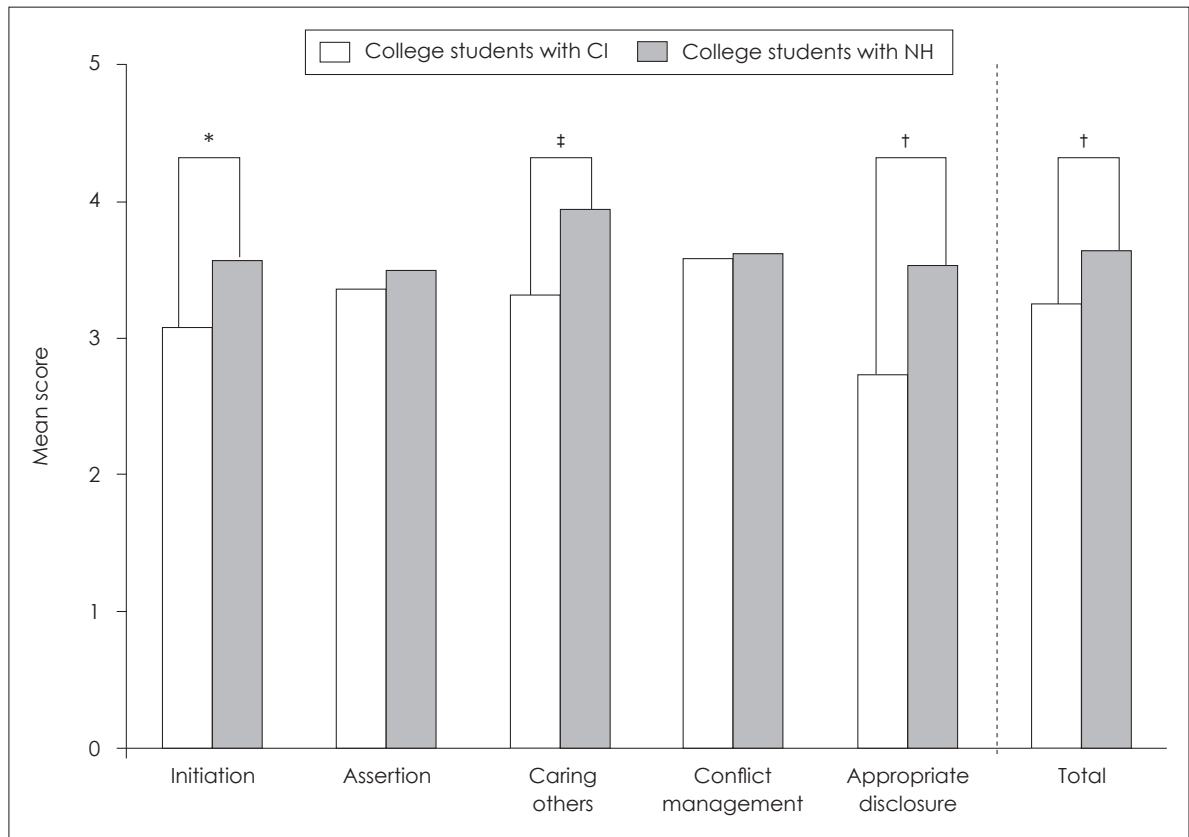

Fig. 1. Comparison of interpersonal competence between college students with $\mathrm{Cl}$ and college students with $\mathrm{NH} .{ }^{*} p<0.05,{ }^{\dagger} p<0.01,{ }^{\ddagger} p<0.001$. $\mathrm{Cl}$ : cochlear implants, $\mathrm{NH}$ : normal hearing.

Table 2. The mean test score on speech perception, receptive vocabulary and speech intelligibility of college students with cochlear implants

\begin{tabular}{lcc}
\hline & Pre-lingual deafness $(n=16)$ & Post-lingual deafness $(n=7)$ \\
\hline Monosyllabic word test (phoneme) & $96.3( \pm 2.4)$ & $94.4( \pm 1.8)$ \\
REVT (raw score) & $158.7( \pm 15.0),(n=13)$ & $167.5( \pm 6.6),(n=4)$ \\
SIR & $4.4( \pm 0.5)$ & $4.6( \pm 0.5)$
\end{tabular}

Values are mean and standard deviation. REVT: Receptive \& Expressive Vocabulary Test, SIR: speech intelligibility ratings 
에 유의한 영향을 주는 변인이 어휘력과 말 명료도인 것으로 나타났기 때문에, 어휘력과 말 명료도에 따른 대인관계 유능 성을 추가로 분석하였다.

인공와우 이식 대학생을 어휘력을 기준으로 어휘력이 부족 한 집단[성인 규준 -2 standard deviation(SD) 미만]과 정상 범 주에 속한 집단(성인 규준 $-2 \mathrm{SD}$ 이상)으로 세분화하여 정상 청력 대학생과 대인관계 유능성을 비교하였다. 어휘력이 부 족한 인공와우 이식 대학생 $(\mathrm{n}=7)$ 은 정상 청력 대학생에 비하 여 대인관계 유능성이 부진하였다 $(p=0.001)$. 하위 영역별로는 관계 형성, 권리 주장, 갈등 관리는 정상 청력 대학생과 유의 한 차이가 없었으나 $(p=0.068, p=0.189, p=0.100)$ 타인 배려와 자기 개방은 인공와우 이식 대학생이 유의하게 부진하였다 $(p=$ $0.000, p=0.001$ )(Fig. 2). 어휘력이 정상 범주에 속한 인공와우 이식 대학생 $(\mathrm{n}=10)$ 은 정상 청력 대학생과 비교하여 대인관계

Table 3. Factors affecting interpersonal competence of college students with cochlear implants

\begin{tabular}{lcc}
\hline & Correlation coefficient & p value \\
\hline Monosyllabic word test & 0.227 & 0.297 \\
REVT & 0.544 & 0.024 \\
SIR & 0.421 & 0.045
\end{tabular}

REVT: Receptive \& Expressive Vocabulary Test, SIR: speech intelligibility ratings
유능성에 차이가 없었다 $(p=0.212)$. 하위 영역별로는 관계 형 성, 권리 주장, 갈등 관리, 자기 개방에서 유의한 차이가 없었 으나 $(p=0.314, p=0.996, p=0.680, p=0.300)$, 타인 배려는 부진 하였다 $(p=0.006)$ (Fig. 3).

말 명료도를 기준으로 인공와우 이식 대학생을 SIR 4(청각 장애인과 대화 경험이 약간 있는 청자에게 문장 발화가 명료 하게 전달되는 수준)와 SIR 5(아동을 포함한 모든 청자에게 문장 발화가 명료하게 전달되는 수준)의 두 집단으로 나누어 정상 청력 대학생과 대인관계 유능성을 비교하였다. SIR 4에 해당하는 인공와우 이식 대학생 $(\mathrm{n}=12)$ 은 정상 청력 대학생에 비하여 대인관계 유능성이 부진하였다 $(p=0.000)$. 하위 영역별 로는 권리 주장과 갈등 관리는 유의한 차이가 없었으나 $(p=$ $0.086, p=0.545)$ 관계 형성, 타인 배려, 자기 개방은 부족하였다 $(p=0.020, p=0.000, p=0.000)$ (Fig. 4). SIR 5에 해당하는 인공 와우 이식 대학생 $(\mathrm{n}=11)$ 은 정상 청력 대학생과 비교하여 대인 관계 유능성에 유의한 차이가 없었다 $(p=0.141)$. 하위 영역별로 는 관계 형성, 권리 주장, 갈등 관리, 자기 개방은 유의한 차이 가 없었으나 $(p=0.153, p=0.848, p=0.782, p=0.128)$, 타인 배려 는 부족하였다 $(p=0.009)($ Fig. 5).

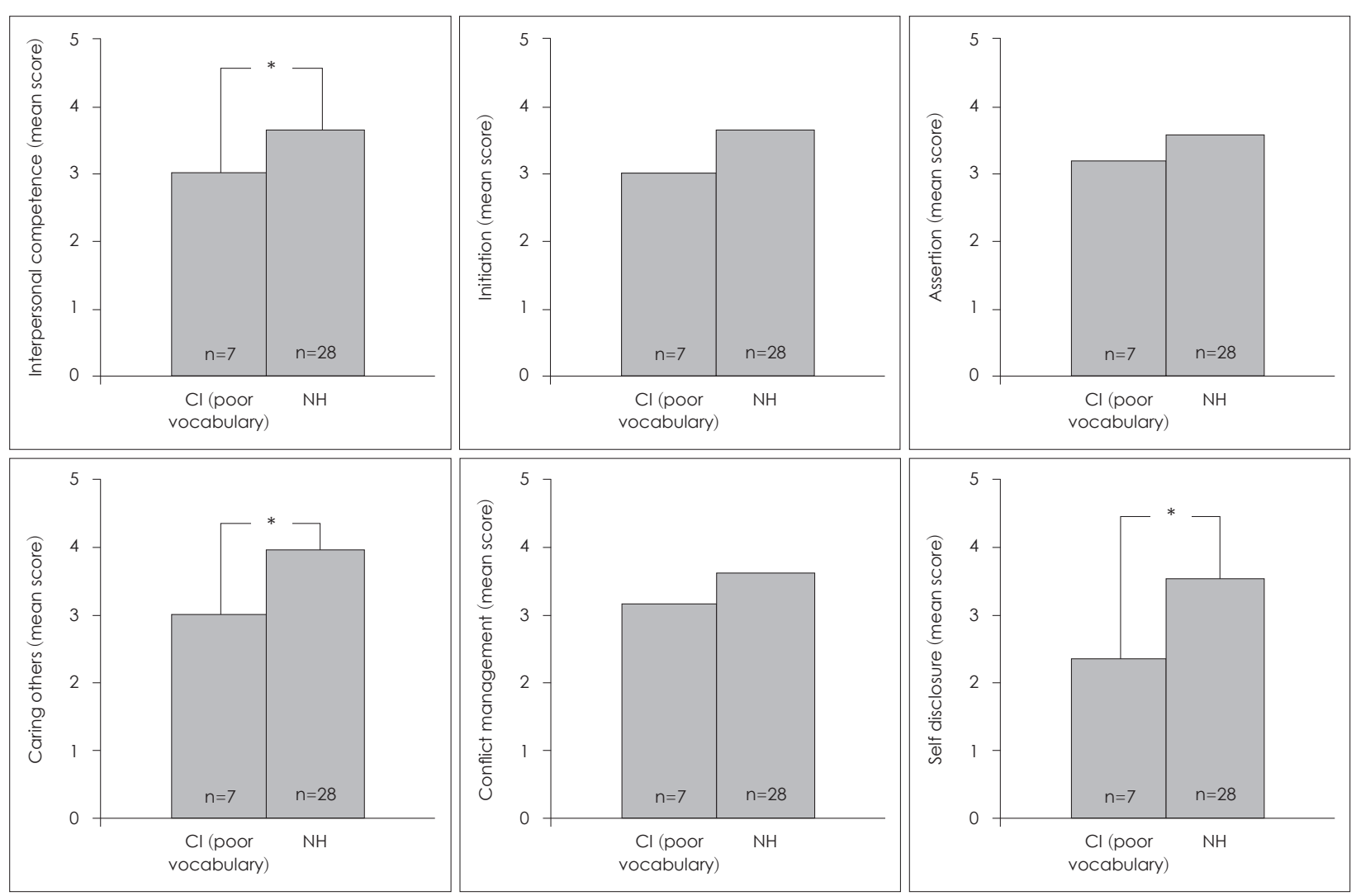

Fig. 2. Comparison of interpersonal competence between college students with $\mathrm{Cl}$ who are poor in vocabulary and college students with $\mathrm{NH} .{ }^{*} p<0.001$. Cl: cochlear implants, $\mathrm{NH}$ : normal hearing. 
Interpersonal Competence in College Students with CI I Choi YM, et al.
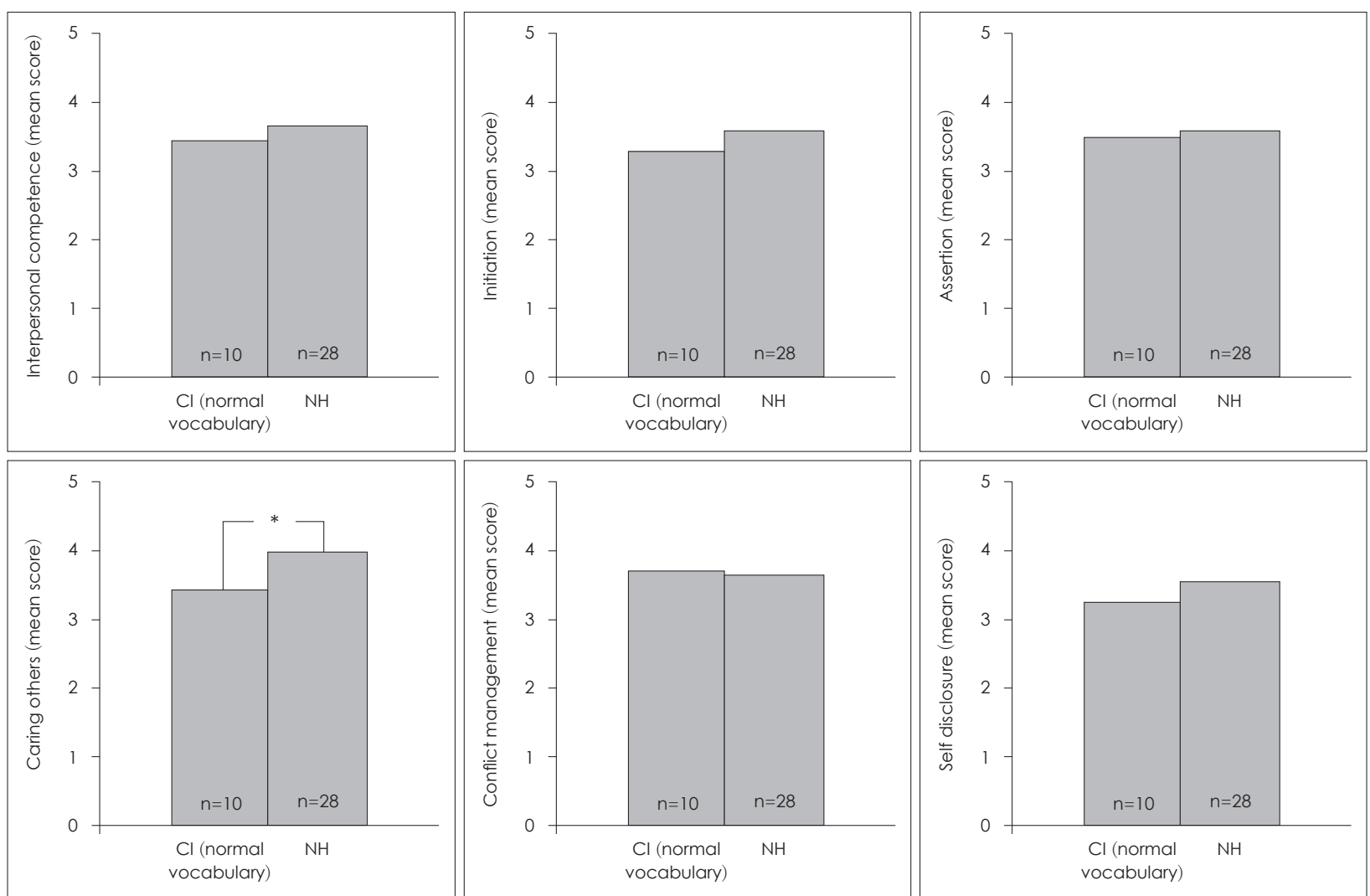

Fig. 3. Comparison of interpersonal competence between college students with $\mathrm{Cl}$ who are normal in vocabulary and college students with $\mathrm{NH} .{ }^{*} p<0.01$. Cl: cochlear implants, $\mathrm{NH}$ : normal hearing.
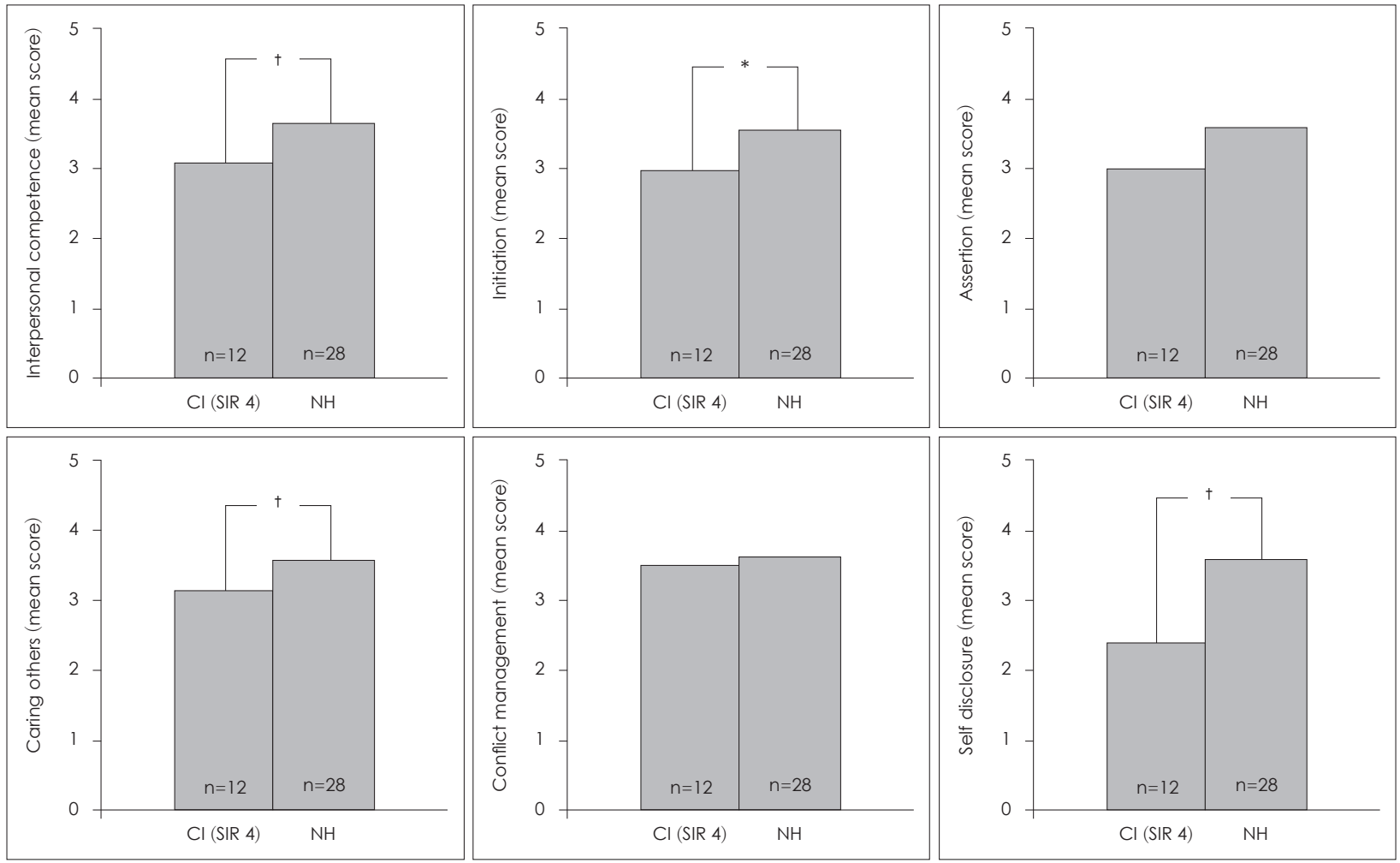

Fig. 4. Comparison of interpersonal competence between college students with $\mathrm{Cl}$ whose SIR score is 4 and college students with $\mathrm{NH}$. ${ }^{*} p<0.05,{ }^{\dagger} p<0.001$. Cl: cochlear implants, $\mathrm{NH}$ : normal hearing, SIR: speech intelligibility ratings. 


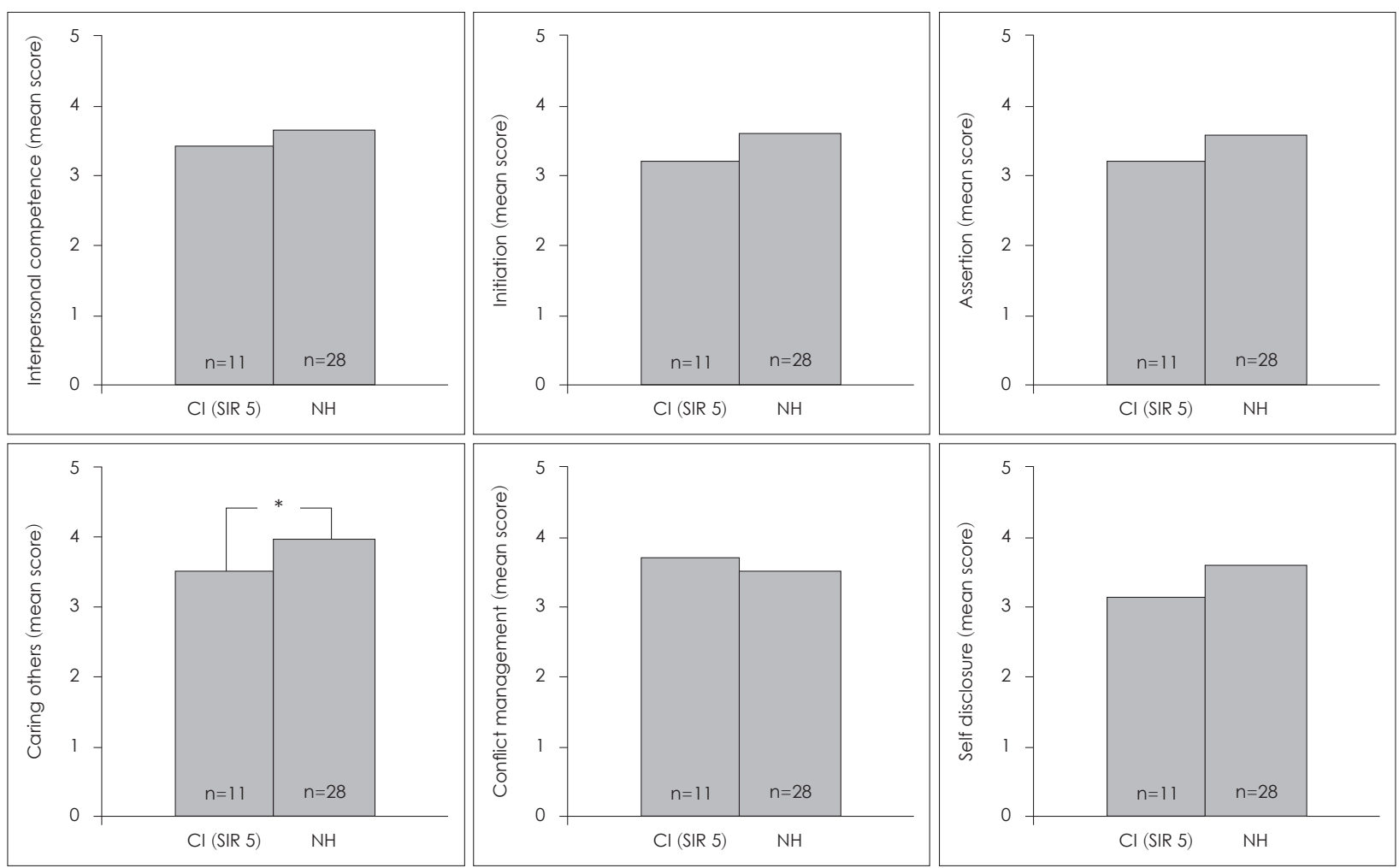

Fig. 5. Comparison of interpersonal competence between college students with $\mathrm{Cl}$ whose SIR score is 5 and college students with $\mathrm{NH}$. ${ }^{*} p<0.01$. Cl: cochlear implants, $\mathrm{NH}$ : normal hearing, SIR: speech intelligibility ratings.

\section{고 찰}

대학생 시기를 포함한 초기 성인기에 친밀한 대인관계를 형 성하는 것이 이후 원만한 사회적 삶을 위해 매우 중요함에도 불구하고, 외국의 선행 연구들은 청각 장애 대학생들이 건청 대학생들과 대인관계에서 많은 어려움을 경험하는 것으로 보고하고 있다. 청각 장애 대학생들은 청각 장애가 있는 친 구, 청각 장애 클럽 혹은 기구와 같은 단체에 의존한 사회적 활동을 하고 있었으며 청각 장애 대학생 중 일부는 정상 청 력 대학생 친구가 있다고 보고하기도 하였지만 대부분 지인 개념의 일시적인 관계에 지나지 않았다.,10) 또한 구화를 사용 하는 청각 장애 대학생들은 구어 능력의 한계로 정상 청력 대 학생들로부터 소외되고, 수화 능력의 한계와 농 문화에 대한 무지로 같은 청각 장애가 있는 대학생들로부터는 거부당하 는 어려움을 겪고 있었다. ${ }^{11}$ 국내 연구에서도 청각 장애 대학 생들은 대인관계에서의 단절과 소외, 관계 형성의 한계를 경 험하고 있는 것으로 나타났다. ${ }^{12}$

구어 의사소통의 어려움으로 인해 발생한 이러한 대인관 계의 어려움이 인공와우 이식을 통해 비교적 원활한 구어 의 사소통 능력을 획득하게 되면 해소될 수 있는지를 알아보고 자 본 연구를 수행하였다. 연구결과 인공와우 이식 대학생의
대인관계 유능성 척도점수는 정상 청력 대학생에 비해 유의 하게 낮은 것으로 나타났다. 그러나 대인관계 유능성의 모든 하위 영역에서 부진한 것은 아니었다. 다섯 가지 하위 역역 중 권리 주장과 갈등 관리 능력은 정상 청력 대학생과 유의한 차이가 없었다. 장애인은 보호의 대상이나 복지의 수혜자가 아니라 스스로의 권리를 증진하고 보호하는 데 중요한 역할을 하는 당사자여야 한다는 측면에서 권리 주장 능력이 정상 청력 대학생과 유의한 차이가 없다는 점은 긍정적이다. 또한 대인관 계에서 발생하는 갈등이 관계를 어렵게 하는 요인이지만 갈등 이 일어났을 때 적절한 갈등 관리 전략을 사용하여 극복하면 이후 서로에 대한 친밀감과 신뢰감이 높아지고 결과적으로 만족스러운 관계가 형성될 수 있으므로 ${ }^{20)}$ 인공와우 이식 대학 생이 정상 청력 대학생과 유사한 갈등 관리 능력이 있다는 점 또한 긍적적이라고 할 수 있다.

반면, 대인관계 유능성의 하위 영역 중 관계 형성, 타인 배 려, 자기 개방 능력은 인공와우 이식 대학생이 정상 청력 대학 생에 비해 유의하게 부진하였다. 그러나 모든 인공와우 이식 대 학생이 정상 청력 대학생에 비하여 이 세 가지 하위 영역의 능 력이 부족한 것은 아니었다. 인공와우 이식 대학생의 대인관 계 유능성을 결정하는 요인은 어휘력과 말 명료도로 나타났고, 이 두 요인에 따라 인공와우 이식 대학생의 대인관계 유능성은 
차이를 보였다. 인공와우 이식 대학생 중 어휘력이나 말 명료 도가 부족한 경우에는 정상 청력 대학생에 비해 대인관계 유 능성이 부족하였으나 어휘력과 말 명료도가 우수한 경우에 는 대인관계 유능성에 있어 정상 청력 대학생과 유의한 차이 가 없었다. 하위 영역별로는 인공와우 이식 대학생 중 어휘력 이 부진한 경우에는 타인 배려, 자기 개방 능력이 정상 청력 대 학생에 비해 부족하였고, 말 명료도가 부진한 경우에는 관계 형성, 타인 배려, 자기 개방 능력이 정상 청력 대학생에 비해 부족한 것으로 나타났다. 선행 연구에서 청각 장애 대학생은 대인관계 단절, 집단에서의 소외, 관계 형성의 한계를 경험한 다고 하였는데 ${ }^{12)}$ 말 명료도가 부족한 인공와우 이식 대학생 의 경우에는 구어 의사소통이 가능하더라도 유창성 결여로 관 계에서 단절과 소외 등 차별적인 경험을 했을 가능성이 있고 이러한 부정적 경험이 관계 형성에서 어려움을 느끼게 하였 을 수 있다. 또한 어휘력이나 말 명료도가 부족한 인공와우 이 식 대학생은 대화를 시작하기 전에는 부족한 부분이 드러나 지 않기 때문에 자기 개방을 의도적으로 회피할 수 있다.

인공와우 이식 대학생 중 어휘력과 말 명료도가 우수한 경 우 대인관계 유능성의 다섯 가지 하위 영역 중 관계 형성, 권 리 주장, 갈등 관리, 자기 개방에서는 정상 청력 대학생과 유 의한 차이가 없었으나, 타인 배려 능력은 정상 청력 대학생에 비해 유의하게 부진한 것으로 나타났다. 대인관계 유능성 척 도검사의 타인 배려 영역은 타인을 적극적으로 배려하는 것 은 물론 상대방이 원할 때 관심을 제공하는 것과 상대를 높 게 평가하고 문제가 생겼을 때에도 그 사람 전체를 비난하지 않는 것을 주요 문항으로 포함하고 있다. ${ }^{19)}$ 이러한 타인 배려 능력을 갖추기 위해서는 자신과 타인의 정서, 신념, 욕구 등 의 내적 심리 상태를 추론하여 상대방의 행동을 예측하거나 설명할 수 있어야 한다. Premack과 Woodruff ${ }^{21)}$ 는 이러한 능 력을 마음이론 능력(Theory of Mind)이라고 명명하였다. 청 각 장애인의 마음이론 능력에 대한 연구는 주로 소아를 대상 으로 이루어져 왔다. 이전의 연구에 따르면 정상 청력 부모를 둔 청각 장애 아동은 마음이론 능력의 발달이 심각하게 지연 되어 있는 것으로 나타났다. ${ }^{22,23)}$ 최근 연구에서는 인공와우 이식을 받은 청각 장애 아동의 경우에는 가족과 구어로 상호 작용이 가능해져 마음이론 능력이 향상된 것으로 나타났지 만 우수한 언어 능력을 가진 인공와우 집단 내에서도 마음이 론 과제에서 실패하는 아동들이 있었고 조기 중재를 받고 언 어 지연도 없는 인공와우 집단에서도 마음이론 발달이 지연 되는 것으로 나타나고 있다. ${ }^{24-27)}$

마음이론 능력의 발달을 위해서는 언어 능력은 물론 풍부 한 상호작용 경험이 중요하다. ${ }^{22,28)}$ 따라서 인공와우 이식 아동 들이 충분한 언어 능력을 습득하고도 마음이론 능력이 부족
한 것은 성장 환경에서 정상 청력 아동과 질적으로 동일한 수 준의 충분한 대인관계 경험을 하지 못하고 있음을 시사한다고 할 수 있다. 실제로 일대일 상황에서 효율적인 의사소통을 할 수 있는 인공와우 이식 아동이라도 다화자 상황이나 소음 상황, 다양한 말소리를 동시에 들어야 하는 상황에서는 어려움을 겪을 수 있다. ${ }^{29-32)}$ 놀이나 대화 상황에서 정상 청력 아동이 듣 는 만큼의 충분한 정보를 얻지 못하면 또래와의 사회적 상호 작용에 방해가 되고 결과적으로 관계에서 어려움이 발생하게 된다. 본 연구의 대상인 인공와우 이식 대학생들의 타인 배려 능력이 정상 청력 대학생에 비해 부족한 것도 이들의 마음이 론 능력의 부족에 기인한 것으로 사료된다.

타인 배려 능력은 타인의 내적 심리 상태를 유추하는 마 음이론 능력의 발달이 전제되어야 한다는 점에서 영유아기 부터 마음이론 능력의 발달을 위한 중재가 필요하다고 할 수 있다. 청각 장애인을 대상으로 한 대인관계 증진 집단상담 프로그램이 대인관계 향상에 도움이 될 수 있으므로 ${ }^{33)}$ 이러 한 프로그램의 개발과 적용이 인공와우 이식 대학생의 대인 관계 유능성 향상에 도움을 줄 수 있을 것으로 기대한다.

본 연구는 23 명의 인공와우 이식을 받은 대학생과 28 명의 건청 대학생을 대상으로 시행되어 연구 대상자의 수가 충분 하지 못한 제한점이 있었고, 건청인을 대상으로 한 선행 연구 에서 개인의 애착과 성향, 사고 특성이 대인관계 유능성과 연 관이 있다고 보고된 바 있어, ${ }^{5,34-36)}$ 후속 연구에서는 더 많은 환자를 대상으로 환자 개인적 특성 및 심리사회적 요인들이 인공와우 이식 환자의 대인관계 유능성에 어떠한 영향을 미 치는지를 알아보고자 한다.

결론적으로 원활한 의사소통 능력을 가진 인공와우 이식 대학생도 정상 청력 대학생에 비해 대인관계 유능성이 유의하 게 낮은 것으로 나타났다. 하지만 어휘력과 말 명료도가 우수 한 인공와우 이식 대학생은 정상 청력 대학생과 비교하여 대 인관계 유능성에 유의한 차이가 없었고, 대인관계 유능성의 다섯 가지 하위 항목 중 하나인 타인배려 능력만 부족한 것으 로 나타났다. 인공와우 이식 대학생의 원활한 대인관계 형성 과 유지를 위해서 어휘력과 말 명료도 향상을 위한 언어 치료 와 함께 타인배려 능력을 함양하기 위한 지원도 함께 고려되 어야 할 것으로 생각한다.

\section{Acknowledgments}

This work was supported by NRF (National Research Foundation of Korea) Grant funded by the Korean Government (NRF-2016-Fostering Core Leaders of the Future Basic Science Program/Global Ph.D. Fellowship Program).

\section{REFERENCES}

1) Spitzberg BH, Cupach WR. Handbook of Interpersonal Competence 
Research. 1st ed. New York: Springer-Verlag;1989. p.1-235.

2) Sullivan HS. Sullivan Conceptions of Modern Psychiatry (Cloth). 2nd ed. New York: WW Norton \& Co;1953. p.30-56.

3) Spitzberg BH, Canary DJ. Loneliness and relationally competent communication. J Soc Pers Relatsh 1985;2(4):387-402.

4) Park K. The effect of negative life stress and interpersonal problem on woman's depression. Kor J Psychol (Health) 2003;8(3):581-93.

5) Bae MJ, JO HI. The relationship between covert narcissism, selfesteem, cognitive/affective empathy and interpersonal competence. Korea Journal of Counseling 2014;15(6):2417-35.

6) Erikson EH. Identity, youth and crisis. 1st ed. New York: W. W. Norton Company;1968. p.91-141.

7) Ju SJ. The effects of human relationships class on university students' interpersonal problem level and interpersonal competence. Korean Journal of Youth Studies 2012;19(7):79-99.

8) Ju HJ. An analysis on job adjustment barriers of new college graduates. The Korean Journal of Human Resource Development Quarterly 2012;14(1):73-93

9) Brown PM, Foster SB. Integrating hearing and deaf students on a college campus: successes and barriers as perceived by hearing students. Am Ann Deaf 1991;136(1):21-7.

10) Murphy JS, Newlon BJ. Loneliness and the mainstreamed hearing impaired college student. Am Ann Deaf 1987;132(1):21-5.

11) Kersting SA. Balancing between deaf and hearing worlds: reflections of mainstreamed college students on relationships and social interaction. J Deaf Stud Deaf Educ 1997;2(4):252-63.

12) Song JY. Qualitative study on difficulties and needs to support of students with hearing impairment in integration: In cases of $\mathrm{N}$ University [dissertation]. Cheonan: Korea Nazarene Univ.;2008.

13) Foster S, DeCaro PM. Mainstreaming hearing-impaired students within a postsecondary educational setting: an ecological model of social interaction. Boston: National Technical Inst. for the Deaf; 1990. p.1-33.

14) Blamey PJ, Sarant JZ, Paatsch LE, Barry JG, Bow CP, Wales RJ, et al. Relationships among speech perception, production, language, hearing loss, and age in children with impaired hearing. J Speech Lang Hear Res 2001;44(2):264-85.

15) Colletti L. Long-term follow-up of infants (4-11 months) fitted with cochlear implants. Acta Otolaryngol 2009;129(4):361-6.

16) Geers AE, Hayes H. Reading, writing, and phonological processing skills of adolescents with 10 or more years of cochlear implant experience. Ear Hear 2011;32(1 Suppl):49S-59S.

17) Nikolopoulos TP, Archbold SM, O’Donoghue GM. The development of auditory perception in children following cochlear implantation. Int J Pediatr Otorhinolaryngol 1999;49 Suppl 1:S189-91.

18) Buhrmester D, Furman W, Wittenberg MT, Reis HT. Five domains of interpersonal competence in peer relationships. J Pers Soc Psychol 1988;55(6):991-1008.

19) Han NR, Lee DG. Validation of he Korean version of the interpersonal competence questionnaire in Korean college students. The Korean
Journal of Counseling and Psychotherapy 2010;22(1):137-56.

20) Jang HS. The effects of conf lict management strategies and communication competence on relational outcomes. Korean Journal of Communication \& Information 2003;(23):113-51.

21) Premack D, Woodruff G. Does the chimpanzee have a theory of mind? Behav Brain Sci 1978;1(4):515-26.

22) Peterson CC, Siegal M. Deafness, conversation and theory of mind. J Child Psychol Psychiatry 1995;36(3):459-74.

23) Peterson CC. Theory-of-mind development in oral deaf children with cochlear implants or conventional hearing aids. J Child Psychol Psychiatry 2004;45(6):1096-106.

24) Remmel E, Peters K. Theory of mind and language in children with cochlear implants. J Deaf Stud Deaf Educ 2009;14(2):218-36.

25) Sundqvist A, Lyxell B, Jönsson R, Heimann M. Understanding minds: early cochlear implantation and the development of theory of mind in children with profound hearing impairment. Int J Pediatr Otorhinolaryngol 2014;78(3):537-43.

26) Ziv M, Most T, Cohen $S$. Understanding of emotions and false beliefs among hearing children versus deaf children. J Deaf Stud Deaf Educ 2013;18(2):161-74

27) Ketelaar L, Rieffe C, Wiefferink CH, Frijns JH. Does hearing lead to understanding? Theory of mind in toddlers and preschoolers with cochlear implants. J Pediatr Psychol 2012;37(9):1041-50.

28) Hao J, Su Y, Chan RC. Do deaf adults with limited language have advanced theory of mind? Res Dev Disabil 2010;31(6):1491-501.

29) Punch R, Hyde M. Social participation of children and adolescents with cochlear implants: a qualitative analysis of parent, teacher, and child interviews. J Deaf Stud Deaf Educ 2011;16(4):474-93.

30) Punch R, Hyde MB. Communication, psychosocial, and educational outcomes of children with cochlear implants and challenges remaining for professionals and parents. Int J Otolaryngol 2011;2011:573280.

31) Rich $S$, Levinger $M$, Werner $S$, Adelman C. Being an adolescent with a cochlear implant in the world of hearing people: coping in school, in society and with self identity. Int J Pediatr Otorhinolaryngol 2013;77(8):1337-44.

32) Bat-Chava Y, Deignan E. Peer relationships of children with cochlear implants. J Deaf Stud Deaf Educ 2001;6(3):186-99.

33) Sung KH, Park JH. Development of group counseling program for improvement of hearing-impaired persons interpersonal relations based upon reality therapy and verification of its effects. J Vocat Rehabil 2015;25(3):25-46.

34) Nam JH. The relations among the big five personality factors, the early maladaptive schema, and interpersonal competence of college students [dissertation]. Daegu: Daegu Univ.;2014.

35) Park YJ, Park WJ. The effects of adult attachment on interpersonal competence-the mediating effects of emotional clarity and negative emotions. Korea Journal of Counseling 2016;17(6):21-41.

36) Lee JS, Chung HJ. The relationships of parent-child relationship and self-differentiation with interpersonal competence among college students. Journal of Family Relations 2016;21(1):99-121. 